\title{
Group Guidance with Gestalt Support \\ Based on Ukhuwah Islamiyah in Madrasah Aliyah, UIN Laboratory, North Sumatra, Medan
}

\author{
Dina Nadira Amelia Siahaan', Zunidar Zuninar² \\ ${ }^{1}$ Universitas Negeri Padang IndonesiA, ${ }^{2}$ UIN Sumatera Utara Medan Indonesia \\ 1dina.nadira@yahoo.co.id, ${ }^{2}$ zunidar@uinsu.ac.id
}

Submitted : 2020-04-22, Revised : 2020-05-14, Accepted : 2020-05-22

\begin{abstract}
Ukhuwah Islamiyah is an equivalent term for good social interaction between individuals in Islam. The concept of ukhuwah or brotherhood can be realized through guidance and counseling efforts. In the "world" this guidance and counseling effort is known as group guidance services. This paper aims to examine group guidance in improving ukhuwah Islamiyah through a gestalt approach with discussion techniques at Madrasah Aliyah Laboratory (MAL) UIN North Sumatra Medan. This research is focused on how the group guidance service efforts with discussion techniques in improving ukhuwah Islamiyah at MAL UIN North Sumatra Medan and what factors support and hinder the process. For this reason, a qualitative approach with a descriptive-analytical method is appropriate to uncover empirical truths of research. The results of this study indicate that group counseling services with discussion techniques can improve student ukhuwah Islamiyah at MAL UIN North Sumatra Medan. This is indicated by (1) good interpersonal communication between students; (2) students' familiarity in finding solutions to shared problems; (3) tolerance of differences in argumentation; and (4) empathy for the situation felt by peers.
\end{abstract}

Keywords: Discussion; Gestalt Approach; Group Guidance; Ukhuwah Islamiyah.

\section{Introduction}

Guidance and counseling is a scientific discipline that helps students achieve selfmaturity. Assistance provided by the guidance and guidance teacher in an effort to train students consciously and independently can be done by each group. Group counseling and guidance services are services aimed at developing communication and communication skills, both for peers, children, and adults. This is in line with the opinion Restyowati \& Naqiyah (2012) Group guidance services can help students who help social conversation with their environment. Typically, this experiment is carried out with a variety of techniques, answering through discussion techniques that "turn on" group dynamics, to foster a sense of togetherness and brotherhood between students.

The urgency of group guidance services is needed in the current era. Because, social phenomena that arise among students, shows the "erosion" of social attitudes among students. This can be seen from the low number of students, who never exchanged greetings with greetings, difficulty in group work, difficulties with low differences, increased efforts to help friends (responses), and low empathy among students. One that can support students in learning is to establish good relationships and interactions with peers, to make this happen it is needed guidance and group counseling services (Oktaviyani, Yusmansyah, \& Zulkifli, 2013). In line with that, counseling guidance is a profession that helps students in problem-solving and provides solutions to problems, however, the "final way" remains in the hands of the counselee himself (Syafaruddin, 2017). In line with this, Sholihah (2019) Think about the importance of group management in helping students leave behind the bad habits that the habit has in you. Based on this, of course guidance and counseling through group guidance services can be used as an alternative to increasing students' social sensitivity, harmonizing in facilitation, which is summarized in the term ukhuwah Islamiyah.

Ukhuwah Islamiyah is a strong brotherly relationship between humans that is lived with a sense of love and is based on Islamic faith (Anshori, 2016). As Muslims, of course, group coaching is given to students, ideally for the "frame" of ukhuwah Islamiyah, by paying attention 
to the social concepts that are intertwined among students. Ukhuwah Islamiyah fellow Muslims is an important thing, it is related to a Muslim must be able to help each other with fellow Muslims, to strengthen Muslims who have just begun to seek disintegration (separation) which is motivated by various differences (Marhaban, Adab, \& Langsa, n.d.). To convince ukhuwah Islamiyah in educational institutions, it can be done using group guidance services for students. This can be done with a variety of techniques, in discussing discussion techniques (Maharani, Masya, Janah: 2018). Furthermore, discussion techniques can stimulate students to communicate intensely and solve problems together in a group (Masya \& Efendi, 2015).

The isolation of the State Islamic Higher Education Institution (PTKIN) in Indonesia specifically which houses the Educational Workforce Education Institute (LPTK) brings together educators and education personnel for the education below, namely basic education and secondary education. Likewise, there are some PTKIN that have opened laboratories consisting of madrasas as a derivative from the campus and related faculties, call it the Faculty of Tarbiyah and Teacher Training of UIN North Sumatra Medan. In the Faculty of Tarbiyah and Teacher Training UIN North Sumatra Medan is a faculty that fully equips competent educators and education staff for the education units below (primary and secondary education), then established a madrasa-based education laboratory in 1994 (Madrasah Aliyah) under the Khairu foundation Ummah, is also a derivative of UIN North Sumatra Medan.

Structurally, the Chancellor of UIN SU Medan is the Supervisor of Madrasah Aliyah Laboratory (MAL) of UIN North Sumatra Medan, then coordinated by the Dean of FITK, and continues the Madrasah Head and personnel of MAL UIN SU Medan. The number of educators in the madrasa is 32 permanent teachers, plus 8 education staff (employees) so that the total is received by 40 educators and education staff. At present, MAL UIN SU Medan opens 4 class majors, namely Social Sciences (IPS), Natural Sciences (IPA), Mathematics and Natural Sciences (MIA), and Religion (AG) classes. In the 2017/2018 school year, the total number of students is 307 students (131 Men and 176 women), then in the 2018/2019 school year the total number of students is 346 students (137 boys and 209 girls), and in the 2019 school year / 2020 the total number of students is 415 students (148 boys and 267 girls).

MAL UIN SU Medan in meeting the needs of the community and answering public confidence in quality education and safety for students. For this reason, according to the institutional vision, the madrasa seeks to provide services to students by facilitating activities to strengthen brotherhood or ukhuwah Islamiyah. In practice, this service is left to the counselors. The guidance and counseling services that have been carried out at the Madrasah Aliyah Laboratory (MAL) of UIN North Sumatra Medan, such as group guidance services in each semester to students, efforts to foster Islamic, scientific, and Indonesian-ness at once to students, and carried out efforts to train competitive attitudes and creative students, by emphasizing collaborative and collaborative attitudes.

The group advisory service activity provided carries a discussion topic involving Gadgets and social media. Based on the answers given by the guidance and counseling teacher, one of the guidance and counseling teachers at MAL UIN SU Medan, "this kind of service is to support aspects of understanding and supporting students, both understanding the negative and positive sides of gadgets and social media, as well as student support from the negative impact of gadgets and social media. Based on the preliminary study, joint discussions and collaboration between students were carried out by the madrasa through "normal" discussion techniques, but were able to support forums and stimulate students' social-emotional relations, as well as ukhuwah Islamiyah among students.

Based on this, it is important to study more importantly related to group guidance services in alleviating the problems of current social phenomena among students related to peer problems and bully difficulties that undermine the value of ukhuwah Islamiyah, also related to fostering relationships between individuals and siblings (choice of ukhuwah). For this reason, 
research is summarized in the theme: Conducting Group Guidance with the approval of the Ukhuwah Islamiyah-Based Gestalt at the Madrasah Aliyah Laboratory (MAL) UIN North Sumatra Medan.

\section{Methods}

This research encourages the analysis of group guidance services conducted at MAL UIN Medan Utara through discussion techniques. This scientific research aims to describe the efforts of group accompaniment, the factors that support and encourage in increasing ukhuwah Islamiyah among students of MAL UIN North Sumatra Medan. The reason, qualitative use can be used to obtain data and reveal the truth in this study (field research). Obtaining research data is done by in-depth interview techniques, participant observation, and study documents. Then the data is carried out continuously through data reduction techniques, data presentation, and drawing conclusions. Then, for the validity of the data, inspection techniques are performed, bound credibility, dispute, dependency, and firmness / confirmability. Looking at the description above, simple flow of research assistance groups with discussion techniques in improving ukhuwah Islamic students can be seen in the picture below.

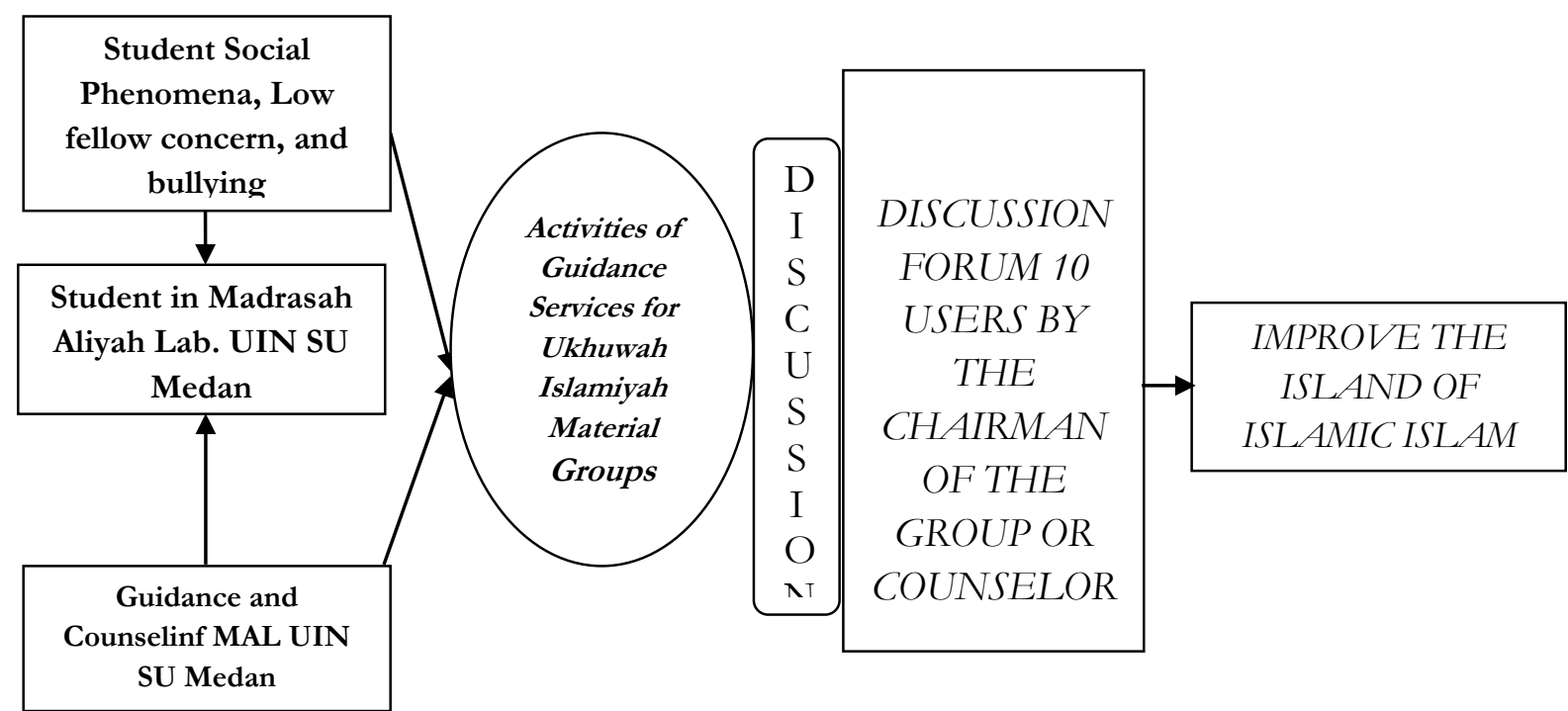

Figure 1. group guidance service with discussion techniques to improve English students

\section{Results and Discussion}

A. Group Guidance Services Efforts at MAL UIN North Sumatra Medan

Group guide services are services provided to individual groups of 5-10 people, each member having the same problem (Jannah, 2015). Increase social sensitivity and to increase empathy and increase everyone's egalitarianism (Haryati, Wibowo, \& Mulawarman, 2017). By fostering empathy and social sensitivity, students can improve the ukhuwah Islamiyah race among others.

The group guidance service technique that has been carried out by the madrasa is a discussion technique that aims to stimulate student socializing activities so that overall it can be developed and proactive. This is because in discussion techniques students can learn to discuss and discuss topics that will be discussed together and find a way out of the debate (Mufidah \& Nursalim, 2008). This is in accordance with what Gestalt discussed which helps students to be independent who help present themselves, socialize well with peers, able to challenge and challenge what happens to individuals (Sari, 2019). 
Based on observations, group guidance activities carried out by guidance and counseling teachers and 15 students in the classroom, discussing and arguing with each other. Likewise, in the discussion session, students are given an affirmation by the teacher to be collected with the students must struggle and be able to solve the problem in question. This was justified by the Head of Madrasah (MAL UIN-SU Medan) who explained that the guidance and counseling activities continue to be carried out in madrasas in an effort to help students through each phase of development to the maximum. Possible, selfconcept in individual and social negotiations can be understood by children well.

Observe student activities in the madrasa, make some changes during the group guidance discussion forum conducted by the teacher guidance and counseling. This is marked by the attitude of the students who issued opinions about and who did not "drop" the interlocutors, the attitude of empathy that talked about students over the conflicts made by peers, as well as responses to help the difficulties that accept peers.

Based on the description above, group assistance was discussed with Gestalt through student assistance discussion activities to improve the fabric of the concept of ukhuwah Islamiyah (Shihab, 1996). The essence of the attitude shown lies in how students perceive their friends as siblings.

B. Factors Encouraging and Hampering Group Guidance Service Activities at MAL UIN North Sumatra Medan

The nature of the problem experienced by the client illustrates imperfections in thinking and the client's error in declaring defeat to the environment (Hadi \& Radiyatul, 2014). The provision of group guidance services aims to provide awareness and understanding to students, that the main problem they face is how to "make peace" with oneself and will continue to create a sense of peace with the concept of ukhuwah Islamiyah when socializing and adapting in the madrasa environment (Asnawi, 2017).

Group guidance service is a guidance and counseling activity that aims to help students achieve social and emotional development well in the madrasa/school environment (Alamri, 2015). Achieving that, of course, is related to the factors that support and help the activities given to students.

While supporting factors or supporting group assistance activities at MAL UIN North Sumatra Medan, namely, full support from the madrasa for guidance and counseling assistance, support from family (guardians) of students. In line with this, Saragi, Iswari, \& Mudjiran (2016) stated that their role was very supportive of guidance and counseling in the school or madrasa environment.

Comment on the supporting factors above, Devianti (2015) explain about the assistance given to children in achieving maximum development, it requires full contributions and assistance from teachers, and peers. Improving, optimizing children's development will be fostered in the school or madrasa environment.

The inhibiting factor of group guidance service activities at MAL UIN North Sumatra Medan that is; (1) the preparation of the guidance and counseling program has not been aligned with the basic concepts of the preparation of the guidance and counseling program, (2) There are some guidance and counseling teachers who do not fit the profession as guidance and counseling teachers, (3) inadequate infrastructure in realizing the conductivity of group guidance services, (4) lack of openness of students in conveying the problems faced, and (5) avoid cooperation between guidance and counseling personnel in madrasas.

This is in line with opinion Nurrahmi (2015) which states that effective counseling guidance services will run if a guidance and counseling teacher has competent expertise, namely, have insight into counseling, have knowledge of approaches, techniques in 
guidance and counseling, conduct guidance and counseling programs, have knowledge related to sources and media for guidance and counseling, have knowledge related to assessment and evaluation of results and the process of guidance and counseling services, manage guidance services and counseling. This effort can be done by guidance and counseling teachers in madrasas as an effort to realize ukhuwah Islamiyah in MAL UIN North Sumatra Medan.

C. Group Guidance Services in Improving Ukhuwah Islamiyah at MAL UIN SU Medan

Group guidance with Gestalt practices the concepts of full awareness, full contact, and full support (Rahman, 2017). Gestalt Therapy helps individuals to achieve awareness about what they feel and do, understand reality and take responsibility for their choices and overcome individual anxieties about possibilities that have not yet occurred in the future (Husniah \& Ulfa, 2019). By implementing this, it can provide reinforcement of the ukhuwah dimension in the madrasa environment.

The concept of full awareness was raised by the teacher in the group discussion forum. This aspect is intended as an effort to encourage students to carry out an activity, both individually and in groups on the basis of a personal agreement. Necessary, intrinsic impression takes precedence over other extrinsic motivations. Allah SWT, so that in strengthening the ukhuwah Islamiyah can be done in accordance with one's own commitment to getting the blessing of Allah SWT (Mujahidin, Rahman, \& Aqilah, 2020).

Full contact in the discussion, "deliberately" given by the teacher guidance and counseling to students in group guidance assistance. Because the guidance and counseling teacher who is present accepts the person who is solving the problem, asking the supervisor who is asked to stimulate the students to solve the problem requested. Needed, the principle of guidance and counseling in group application can be implemented well.

As for the aspect of full support, it becomes an extremely important impetus for the success of group guidance services. The full support can come from the teachers, the madrasas as a whole, or from the guardians or parents of students. So, with the power of collaboration, students increasingly feel confident individually, and cooperate with each other socially, for the support of a conducive climate in school.

Group guidance services are carried out in the form of 4 (four) activities, namely preparation, service activities, core activities, and elections. Held for the duration of 90 minutes, for class X students, in one of the classrooms with a variety of literacy sources to be used as discussion material related to the topic carried, namely "change the gadget social media". During the group guidance process, the counselor is seen giving students an understanding of the thinking from social media gadgets. Of course, the only negative impact that needs to be considered, because it is related, also has such a large positive side in the change and progress of the present time for humans. This is done during the allotted time using discussion techniques.

The discussion technique is carried out by the school in gathering students to interact with each other, communicate and talk in a group. Guidance and direction given in groups are optimized by supervision by the group leader, who incidentally is a counselor at MAL UIN North Sumatra Medan. This is in line with the opinion Maulana dan Hidayati (2016) which states that discussion techniques can be used to improve interpersonal communication between individuals.

Based on the guidance counseling report document, "group guidance service" MAL UIN SU Medan, there were 10 (ten) students who took group guidance service on Monday, February 17, 2020, namely Amanda Putri Lubis, Siti Rika Amanda, Nurul Fadhilah Siregar, Nabilah Aprilia Artanti, Anggi Dwi Kiarani Siregar, Harilaksono, M. Langga Madjid, Niki Safdina Batubara, Meilina Hizlia, dan Rizka Ramadhani. 
Evaluating the service activities, there are 3 (three) aspects which are reviewed as material for evaluating the activities namely student responses, student activeness, and student changes. The technique used is group discussion and home space. The following is a description of the three aspects assessed earlier.

1. Student Response

When implementing group guidance student responses were quite good. According to the guidance and counseling teacher,

"This can be seen from the attitude of students who want to provide compilation answers that I ask and the preparation given by students who have a response that is quite active in following the ongoing activities. At first, students do not dare to express or issue opinions that they want to express because they are afraid if they answer incorrectly. Then I give support to students that there are no right or wrong answers. After students begin to actively respond to what is asked by the counselor. "

Comment on the quote above, Yanti (2015) In this regard stimulating students' responses is necessary to try, be well-maintained knowledge, appreciation, and approval of actions from students. The response received by students is able to achieve which development has been achieved by each student.

Based on the description above, discussing student responses becomes important which is reviewed by the guidance and counseling teacher in carrying out the group guidance task. Cause, which responses were acceptable to students made and resolved which ones were agreed to be achieved.

2. Student activity

As stated above, students actively participate in group guidance programs. Cause there is reciprocity done by students, students who compile do not know what has been agreed by the student counselor to ask without fear. The activeness of students can also be seen from the gestures that look very enthusiastic in the implementation of group guidance.

3. Student change

After conducting group counseling activities, students experience changes in terms of communication, namely in opinion, students begin to contribute, which in the initial stages the counselor thinks students will find it difficult to communicate, but in practice students give opinions about the material provided.

Indeed, if the frequency and quality of discussions about ukhuwah Islamiyah replace the implementation well. Furthermore, practiced by teachers and students every day, the quality of ukhuwah is increasing. Furthermore, there are four aspects that are shown progress in improving ukhuwah Islamiyah at MAL UIN North Sumatra Medan, namely; good interpersonal communication between students, students' familiarity in finding joint solutions; difference of opinion over differences of argument; and empathy for peers.

\section{Conclusions and Suggestions}

The results of this study indicate that group counseling services with discussion techniques can improve student ukhuwah Islamiyah at MAL UIN SU Medan. This is characterized by good interpersonal communication between students, students' familiarity in finding solutions to shared problems, tolerance for differences in argumentation and empathy for situations felt by peers. The factors supporting or supporting group assistance activities at MAL UIN North Medan, namely; full support from the school for guidance and counseling assistance, support from the family (guardian) students. The inhibiting factors of group guidance service activities at MAL UIN North Sumatra Medan namely, the preparation of 
counseling and counseling programs have not been aligned with the basic concept of guidance and counseling programs, there are several counselors whose educational background is not in accordance with the counselor's profession, inadequate infrastructure facilities in realizing the conductivity of group guidance services, the lack of openness of students in presenting problems encountered, and the lack of cooperation between personnel of guidance and counseling in madrasas.

The results of this study can be used as reference material for those related to group guidance using the gestalt approach, so that researchers can further develop research related to the gestalt approach with other techniques in improving ukhuwah Islamiyah.

\section{References}

Al-Qur'an al-Karim. (2009). -Qur'an Terjemah dan Asbabun Nuzul: Al-Malik (The Brave). Surakarta: CV. Al-Hanan.

Alamri, N. (2015). Layanan Bimbingan Kelompok Dengan Teknik Self Management Untuk Mengurangi Perilaku Terlambat Masuk Sekolah (Studi Pada Siswa Kelas X SMA 1 Gebog Tahun 2014/2015). Jurnal Konseling GUSJIGANG, 1(1).

Anshori, C. S. (2016). Ukhuwah Islamiyah Sebagai Fondasi Terwujudnya Organisasi Yang Mandiri dan Profesional. Jurnal Pendidikan Agama Islam-Ta'lim, 14(1), 117-125.

Asnawi, K. U. (2017). Konsep Konseling Gestalt Berbasis Islam Untuk Membantu Meningkatkan Bersosialisasi Dan Adaptasi Siswa Di Sekolah. Hisbah: Jurnal Bimbingan Konseling Dan Dakwah Islam, 14(1), 1-14.

Devianti, R. (2015). Kontribusi Dukungan Orangtua, Teman Sebaya, dan Guru Bimbingan dan Konseling terhadap Minat Siswa pada Jurusan yang Ditempati di SMA. Jurnal Konseling Dan Pendidikan, 3(2), 22-30.

Hadi, S., \& Radiyatul, R. (2014). Metode pemecahan masalah menurut polya untuk mengembangkan kemampuan siswa dalam pemecahan masalah matematis di sekolah menengah pertama. EDU-MAT: Jurnal Pendidikan Matematika, 2(1).

Haryati, A., Wibowo, M. E., \& Mulawarman, M. (2017). Model Bimbingan Kelompok Teknik Sosiodrama untuk Meningkatkan Empati Siswa SMP. Jurnal Bimbingan Konseling, 6(1), 28-33.

Husniah, W. O., \& Ulfa, M. (2019). Mengurangi Kecemasan Siswa Dalam Menghadapi Ujian Semester Melalui Konseling Kelompok Gestalt. Psikologi Konseling, 15(2).

Jannah, N. (2015). Pelaksanaan Layanan Bimbingan Kelompok dalam Pemilihan Kegiatan Ekstrakurikuler di SMP Negeri 1 Rantau. Jurnal Mahasiswa BK An-Nur, 1(1).

Marhaban, H., Adab, F. U., \& Langsa, D. I. (n.d.). Membina Ukhuwah Islamiyah Berdasarkan Petunjuk Al Quran.

Masya, H., \& Efendi, A. (2015). Implementasi Bimbingan Kelompok dengan Tekhnik Diskusi untuk Meningkatkan Minat Belajar Peserta. KONSELI: Jurnal Bimbingan Dan Konseling (E-Journal), 2(1), 13-20.

Maulana, M. A., \& Hidayati, A. (2016). Penggunaan Layanan Bimbingan Kelompok Teknik Diskusi Untuk Meningkatkan Kemampuan Komunikasi Interpersonal Mahasiswa Bimbingan Dan Konseling Univet Bantara Sukoharjo Angkatan Tahun 2015/2016. Edudikara: Jurnal Pendidikan Dan Pembelajaran, 1(1), 67-72.

Mufidah, L., \& Nursalim, M. (2008). Penggunaan Bimbingan Kelompok Dengan Teknik Diskusi Kelompok Untuk Meningkatkan Minat belajar Siswa. On-Line), Https://www. 
Scribd. Com/Doc/189875894/Penggunaan-Bimbingan-Siswa.

Mujahidin, E., Rahman, I. K., \& Aqilah, F. N. (2020). Pendekatan Bimbingan Dan Konseling Gestalt Profetik (G-Pro) Untuk Meningkatkan Toleransi Beragama Siswa Di SMA Ibnu 'Aqil. Edukasi Islami: Jurnal Pendidikan Islam, 9(01), 99-126.

Nurrahmi, H. (2015). Kompetensi profesional guru bimbingan dan konseling. Jurnal Dakwah Alhikmah, 9(1), 45-55.

Oktaviyani, N., Yusmansyah, Y., \& Zulkifli, R. R. (2013). Peningkatan Interaksi Sosial SIswa dengan Teman Sebaya Melalui Layanan Konseling Kelompok. ALIBKIN (Jurnal Bimbingan Konseling), 2(4).

Rahman, I. K. (2017). Gestalt Profetik (G-PRO) Best Practice Pendekatan Bimbingan dan Konseling Sufistik. Konseling Religi: Jurnal Bimbingan Dan Konseling Islami, 8, 151172.

Restyowati, D., \& Naqiyah, N. (2012). Penerapan teknik permainan kerja sama dalam bimbingan kelompok untuk meningkatkan kemampuan interaksi sosial pada siswa. Jurnal Psikologi Pendidikan Dan Bimbingan, 11(2).

Saragi, M. P. D., Iswari, M., \& Mudjiran, M. (2016). Kontribusi Konsep Diri Dan Dukungan Orangtua terhadap Motivasi Belajar Siswa dan Implikasinya dalam Pelayanan Bimbingan dan Konseling. Konselor, 5(1), 1-14.

Sari, N. L. (2019). Penggunaan Konseling Gestalt Untuk Meningkatkan Self Awareness Siswa Pada Kelas XI di SMA Negeri 8 Bandar Lampung Tahun Ajaran 2017/2018.

Shihab, M. Q. (1996). Wawasan Al-Quran: Tafsir Tematik atas Pelbagai Persoalan Umat. Mizan Pustaka.

Sholihah, A. N. (2019). Restrukturisasi Kognitif dengan Setting Kelompok untuk Mengurangi Kecanduan Online Game Remaja. KONSELI: Jurnal Bimbingan Dan Konseling (EJournal), 6(1), 33-42.

Syafaruddin, S. (2017). Bimbingan dan konseling: Perspektif Al-quran dan sains Prosiding Bimbingan Konseling Fakultas Ilmu Tarbiyah dan Keguruan UIN Sumatera Utara. perdana. 